\title{
Density and exposure of surface-pelagic juvenile sea turtles to Deepwater Horizon oil
}

\author{
Trent L. McDonald ${ }^{1, *}$, Barbara A. Schroeder ${ }^{2}$, Brian A. Stacy $^{2}$, Bryan P. Wallace $^{3,4}$, \\ Leigh Ann Starcevich', Jonathan Gorham ${ }^{5}$, Mandy C. Tumlin ${ }^{6}$, Dave Cacela ${ }^{3}$, \\ Matthew Rissing ${ }^{3}$, Danya B. McLamb ${ }^{7}$, Eric Ruder ${ }^{7}$, Blair E. Witherington ${ }^{8}$ \\ ${ }^{1}$ Western EcoSystems Technology, Inc., Laramie, WY 82070, USA \\ ${ }^{2}$ Office of Protected Resources, NOAA Fisheries, Silver Spring, MD 20910, USA \\ ${ }^{3}$ Abt Associates, Inc., Boulder, CO 80302, USA \\ ${ }^{4}$ Nicholas School of the Environment, Duke University Marine Lab, Beaufort, NC 28516, USA \\ ${ }^{5}$ In-water Research Group, Jensen Beach, FL 34957, USA \\ ${ }^{6}$ Louisiana Department of Wildlife and Fisheries, Baton Rouge, LA 70808, USA \\ ${ }^{7}$ Industrial Economics, Inc., Cambridge, MA 02140, USA \\ ${ }^{8}$ Disney's Animals, Science and Environment, Lake Buena Vista, FL 32830, USA
}

\begin{abstract}
The 2010 Deepwater Horizon (DWH) oil spill posed a severe threat to surface-pelagic sea turtles because the surface convergence zones, which provide vital habitat by aggregating pelagic Sargassum and other floating material, also aggregated floating oil. Following the DWH spill, turtle rescue operations between 17 May and 9 September 2010 documented 937 juvenile sea turtles in the spill area and examined 574 captured turtles. Of the captured turtles, $81 \%$ were visibly oiled. Transect searches in convergence zones found Kemp's ridleys (51\% of individuals), green turtles $(37 \%)$, loggerheads $(7 \%)$, hawksbills $(2 \%)$, and unidentified sea turtles $(2 \%)$. Linetransect methods estimated the density of all surface-pelagic sea turtles in surface convergence zones to be $3.32 \mathrm{~km}^{-2}(95 \% \mathrm{CI}=2.82-3.88)$, and the density of heavily oiled turtles to be $0.24 \mathrm{~km}^{-2}$ (95\% CI $=0.15-0.39)$. Turtle densities and the areal extent of heavy oiling probability were used to estimate total number of turtles exposed to DWH oil. We estimate approximately 402000 surface-pelagic sea turtles were exposed, and of those, 54800 were likely to have been heavily oiled. Our estimates formed the basis of surface-pelagic juvenile sea turtle mortality estimates included in the DWH natural resource damage assessment.
\end{abstract}

KEY WORDS: Oil exposure - Gulf of Mexico - Surface-pelagic · Oiling $\cdot$ Loggerhead sea turtle · Kemp's ridley sea turtle · Green sea turtle · Hawksbill sea turtle · Deepwater Horizon oil spill

\section{INTRODUCTION}

During the Deepwater Horizon (DWH) oil spill, surface oil was widely dispersed throughout much of the northern Gulf of Mexico (GoM) and consisted of sheen to thicker layers of viscous petroleum (DWH NRDA Trustees 2015, Section 4.2). The majority of oil from the spill affected oceanic waters, with important effects on surface-pelagic drift habitats in convergence zones that accumulate Sargas-

*Corresponding author: tmcdonald@west-inc.com sum macroalgae, other surface-pelagic organisms, other floating material, and oil (DWH NRDA Trustees 2015, Section 4.2). In the GoM, convergence zones are commonly traced by conspicuous lines of the pelagic brown algae, Sargassum natans and $S$. fluitans (henceforth referred to as Sargassum; Butler et al. 1983, Butler \& Stoner 1984). These zones of Sargassum habitat were extensively oiled during the DWH oil spill (DWH NRDA Trustees 2015, Section 4.2).

(c) The authors and (outside the USA) the US Government 2017. Open Access under Creative Commons by Attribution Licence. Use, distribution and reproduction are unrestricted. Authors and original publication must be credited.

Publisher: Inter-Research · www.int-res.com 
Convergence zones, and the pelagic Sargassum that they contain, provide a vital source of refuge and sustenance for sea turtles in the Atlantic Ocean and GoM (Witherington et al. 2012, Mansfield et al. 2014). Hatchling sea turtles emerge from nests on sand beaches and disperse away from land into surface-pelagic and (primarily) offshore habitats in convergence zones, where they feed, grow, and evade predation for several years or more (Bolten 2003, Witherington et al. 2012). The surface-pelagic turtle population of the northern GoM receives regular influxes of new turtles originating from nesting beaches in several different countries within the GoM and wider Caribbean (Bolten 2003, Bolten \& Witherington 2003, NMFS et al. 2011). Although distribution and dispersal of surface-pelagic juvenile turtles (also referred to as 'oceanic' juveniles) are influenced by currents and other oceanographic features, recent studies have shown that these turtles are active swimmers and do not solely drift (Putman \& Mansfield 2015). Nonetheless, turtles in this life stage are strongly associated with convergence zones and associated habitat (Thiel \& Gutow 2005, Witherington et al. 2012).

This reliance on Sargassum habitats in convergence zones for foraging and shelter made surfacepelagic juvenile turtles particularly vulnerable to extensive surface oiling during the DWH oil spill. Surface-pelagic turtles spend the majority of their time $(97 \%)$ within $1 \mathrm{~m}$ of the surface and tend to remain in or near Sargassum. Witherington (2002) and Witherington et al. (2012) recorded $89 \%$ of over 1800 sightings of post-hatchling (i.e. young of the year, 4 to $8 \mathrm{~cm}$ straight carapace length [SCL]) and juvenile (13 to $28 \mathrm{~cm}$ SCL) sea turtles in the GoM within $1 \mathrm{~m}$ of floating Sargassum. Furthermore, esophageal lavage and fecal samples have revealed that juvenile surface-pelagic turtles consume a diet composed principally of Sargassum-community associated animals, and secondarily of jellies, marine plants (mostly pelagic Sargassum) and insects (Witherington et al. 2012). Their affinity for Sargassum habitats and their broad diet puts surface-pelagic turtles at risk of ingesting many types of floating hazardous material, including petroleum. In fact, Witherington (2002) found that $20 \%$ of live, post-hatchling loggerheads captured in surface-pelagic habitat had ingested tar, and 3 dead turtles were found with ingested tar.

All sea turtles in the GoM are federally listed under the US Endangered Species Act (ESA), and they were among the primary taxa assessed under the DWH natural resource damage assessment (NRDA) (DWH NRDA Trustees 2015, Section 4). Immediately after the onset of the DWH spill and activation of the Regional Response Team on 21 Apr 2010, the National Oceanic and Atmospheric Administration (NOAA) and other agencies (e.g. Florida Fish and Wildlife Conservation Commission, Louisiana Department of Wildlife and Fisheries) recognized the vulnerability of small, surface-pelagic sea turtles to floating petroleum in the spill area. This concern prompted sea turtle rescue efforts, which were subsequently managed under the Unified Command of the US Coast Guard Incident Command System (ICS; USCG 2012). The Operations Section of the ICS supervised the Wildlife Branch that in turn oversaw all wildlife response activities. In May 2010, the Wildlife Branch initiated vessel-based searches of pelagic sea turtle habitat. The objectives of these searches were to document and rescue live oiled turtles (for de-oiling, rehabilitation, and release back to the wild), document and collect dead oiled turtles, and collect information that would enable estimation of the total number of turtles in this life stage exposed to DWH oil. A primary component of the DWH NRDA (DWH NRDA Trustees 2015, Section 4.8) was an extension from exposures to number of turtle mortalities that could be attributed to the spill. In this paper, we describe the conduct of sea turtle rescue operations and surveys, the information collected, and the approach used for estimating the full extent of surface-pelagic sea turtle exposure to DWH oil in the northern GoM.

\section{MATERIALS AND METHODS}

\section{Rescue surveys}

Although the size and remote location of the spill presented challenges, humane intervention on behalf of oiled turtles was a guiding principal of the response. This imperative to save sea turtles under threat from oil influenced the study design ultimately used to calculate turtle densities and exposure estimates. The remainder of this section describes the rescue efforts, in part to provide context for the density and exposure estimates.

Approximately $1 \mathrm{mo}$ after the beginning of the 2010 DWH spill event, wildlife response workers began searching surface waters of the GoM for oiled sea turtles. Observers in aircraft occasionally helped target search areas by communicating the location of oil and likely turtle habitat to surface vessels. The typical surface vessel was 9 to $20 \mathrm{~m}$ long with an elevated platform. Initial opportunistic rescue efforts without aerial support took place out of Venice, LA, 
in May 2010. Wider searches with aerial support began in late May with vessels operating out of Venice and Grand Isle, LA, and by July, multiple vessels operated out of 3 principal ports: Venice; Orange Beach, AL; and Destin, FL. All vessel tracks were recorded by Wide Area Augmentation System (WAAS) GPS. The longitude of searched transects ranged from approximately $89.5^{\circ} \mathrm{W}$ (approximately $50 \mathrm{~km}$ west of Venice) to approximately $85.6^{\circ} \mathrm{W}$ (approximately $60 \mathrm{~km}$ east of Destin). Latitude of searches ranged from approximately $30.4^{\circ} \mathrm{N}$ (shore near Destin) to approximately $28.25^{\circ} \mathrm{N}$ (approximately $90 \mathrm{~km}$ south of Venice) (Fig. 1). Directed searches for surfacepelagic sea turtles concluded on 9 September 2010.

Searches consisted of both on-transect and offtransect efforts. Responders conducted on-transect searches at low speeds (i.e. approximately $8 \mathrm{~km} \mathrm{~h}^{-1}$ ) parallel to or through consolidated patches of surface material. The highest priority search areas contained floating petroleum, emulsified oil, pelagic Sargassum, and flotsam such as marsh reeds and plastics (Fig. 2A). The decision on whether to search a particular area of floating material was based on logistics (e.g. authorization to access the area, distance from shore, distance to the area from current position, time of day) and the perceived likelihood of observing turtles, and not necessarily whether the area was oiled. Responders searched non-oiled areas because oiled turtles could have moved out of oiled surface habitat and into non-oiled habitat (Fig. 2B). Searched areas were typically aligned as linear features, in keeping with the way floating materials define surface convergence, but responders also searched non-linear scattered patches and windrows on-transect.

When turtles were observed during on-transect efforts, observers recorded the species (in most cases)

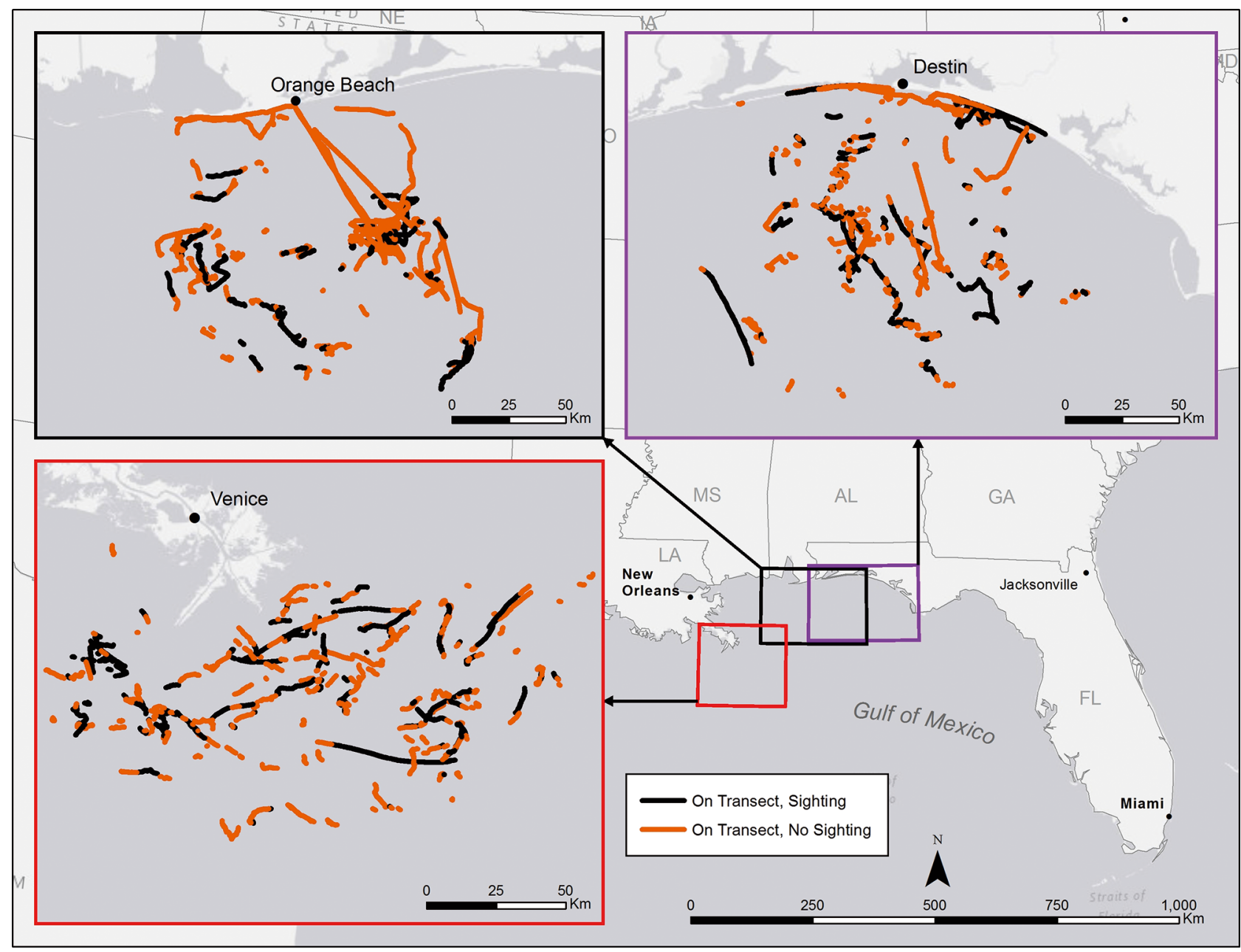

Fig. 1. Ports of operation and transects searched during sea turtle response efforts (insets), following the Deepwater Horizon oil spill, colored by whether turtles were (black) or were not (orange) sighted. The 3 inset maps correspond to the port of operations: Venice, LA, Orange Beach, AL, and Destin, FL. Total length of all transects was $4213 \mathrm{~km}$ 

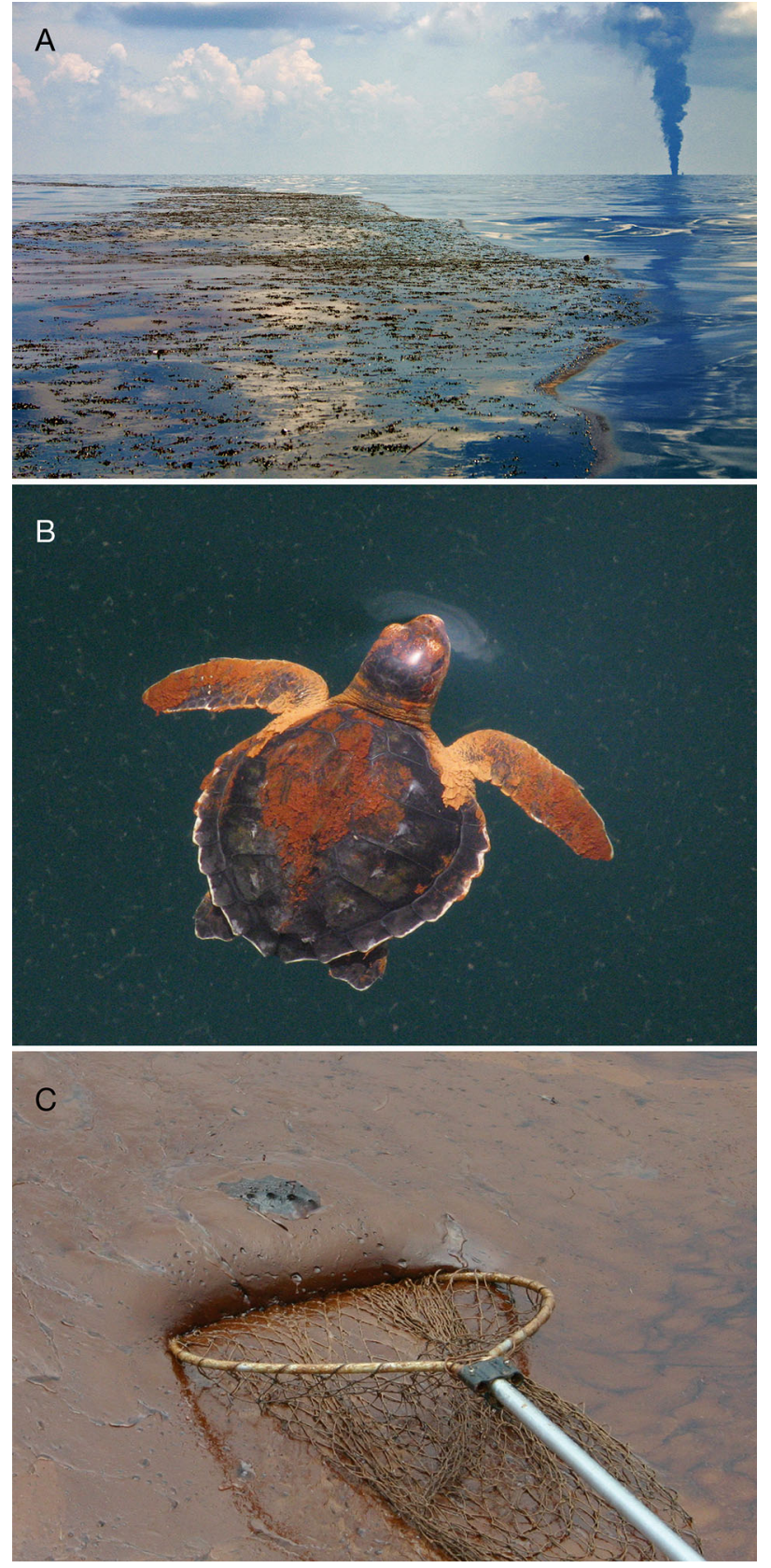

Fig. 2. Types of area searched and sea turtles documented during Deepwater Horizon oil spill rescue operations. (A) A typical consolidated line of oiled pelagic Sargassum and other floating material surveyed for surface-pelagic turtles during sea turtle response efforts. The column of smoke on the upper right is from a similar line that was collected by an oil boom and burned. (B) A juvenile Kemp's ridley in oil sheen adjacent to a sampled convergence zone. This turtle had moderate oil coverage and was photographed immediately before it was captured live by dip-net. (C) A juvenile Kemp's ridley in thick petroleum during collection by dipnet. This turtle had heavy oil coverage and was dead upon recovery. The turtle was kept afloat by the surrounding buoyant mat of grease. Photo credit: (A) and (C) Blair Witherington; (B) Kate Sampson (NOAA) and geographic position of the vessel when perpendicular to the original sighting location. To permit estimates of turtle densities using line-transect methodology (see 'Density estimation' section below), a turtle's perpendicular distance from the vessel's path was measured using one of 2 methods. Perpendicular distances were either (1) computed from angles measured by a hand-held digital inclinometer and height of the vessel's observation platform, or (2) measured directly using graduated marks on the pole of a capture dip-net. When the inclinometer was not available, distances beyond the graduated pole's length ( $4 \mathrm{~m})$ were estimated visually using pole length as a reference. Following collection of sighting data, workers attempted to capture the observed turtle. Turtles were either immediately captured using a dip-net (Fig. 2C), pursued for a short period and captured in the dip-net, or were pursued until they evaded capture by diving, often beneath surface oil and Sargassum. After 19 July 2010, turtles perceived to be 'non-oiled' or that vigorously swam away when initially sighted were no longer pursued, to focus capture efforts on those turtles in greatest need of medical care.

Observers also made off-transect observations and captures of surface-pelagic sea turtles. Off-transect search effort differed significantly from on-transect effort in that vessels moved at a greater speed (i.e. typically while in transit between on-transect target areas), and observers made turtle sightings and captures opportunistically. Due to these methodological differences, the small number of individuals sighted off-transect, and inconsistent search effort, off-transect distance functions could not be estimated and offtransect sightings were excluded from density and exposure estimations. On-board assessments and data collection for turtles captured off-transect were similar to those for on-transect captures.

\section{Oiling assessment}

Following field data collection, photographs and field notes were reviewed to assign captured sea turtles to one of the following 5 oiling categories based on the extent and degree of external oiling: nonoiled, minimally oiled, lightly oiled, moderately oiled, and heavily oiled (Fig. 3). The non-oiled category was assigned to turtles with no visible signs of external oiling. Turtles assigned to the minimally oiled category either had oiling limited to one region of the body or oil coverage that was very light (i.e. thin smear or staining only). Lightly oiled was assigned to 

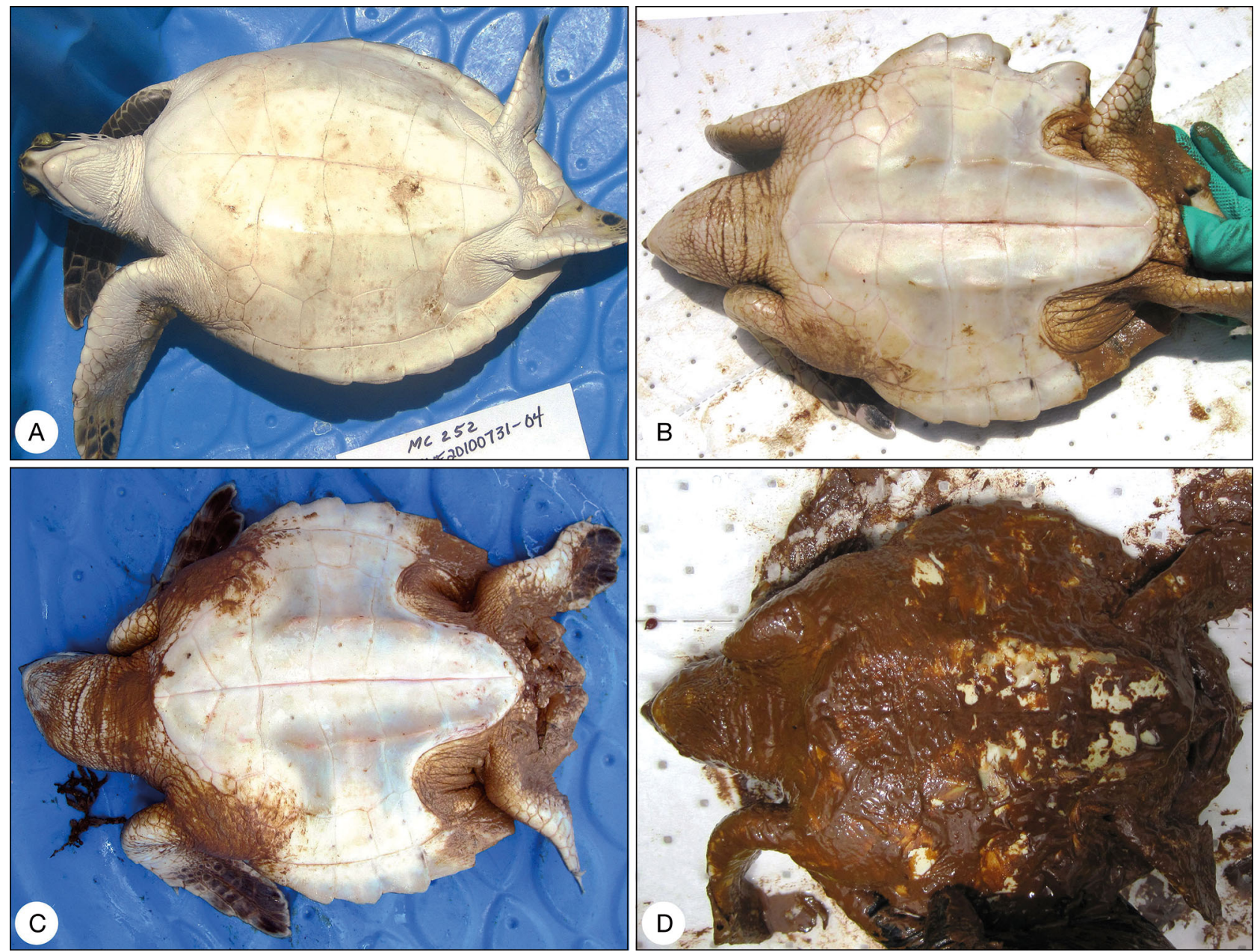

Fig. 3. Representative photos of the ventral side of captured turtles subsequently assigned a positive oiling category. Categories are as follows: (A) minimally oiled; (B) lightly oiled; (C) moderately oiled; (D) heavily oiled (reproduced from Stacy 2012)

turtles with a thin layer of oil lightly covering multiple parts of the body, and to turtles in which thicker aggregated oil, if present, was focally distributed. Moderately oiled was assigned to turtles with heavier layers of oil covering multiple areas of the body, often accompanied by generalized brown staining. Turtles with aggregations of thick, tenacious oil diffusely covering the body were assigned the heavily oiled class. Turtles sighted but not captured were initially assigned to an oiling category of 'unknown.' In addition, field notes, rehabilitation center records, and necropsy findings were reviewed for presence or absence of oil within the mouth and upper digestive tract as an indicator of petroleum ingestion. These evaluations of external and internal oiling, as well as the subsequent oiling categories, provided a primary basis for evaluating the type and extent of adverse oil exposure effects on sea turtles (DWH NRDA Trustees 2015, Section 4.8).

\section{Estimation of turtle density and exposures to oil}

Although the primary aim of the response efforts was humane intervention and rescue of surfacepelagic sea turtles in oiled habitats, a secondary aim was to quantify the density and abundance of exposed turtles in the DWH spill area. The sections that follow describe the statistical estimation procedures used to accomplish these quantitative goals.

\section{Density estimation}

Sighted but un-captured turtles could not be assigned to oiling categories because thorough examination of their oiling status was not possible. Nonetheless, it was clear based on visual observation that at least some non-captured turtles were oiled. Of 240 on-transect sightings of non-captured individuals, 6 
were noted as being visibly oiled, 5 were noted as possibly oiled, and 19 were sighted in oiled environments. A certain proportion of non-captured turtles were very likely to have been oiled, because (1) $12.5 \%$ of non-captured turtles were visibly or likely oiled, (2) crews were unable to examine the ventrum of non-captured turtles (where oiling was often most apparent; Stacy 2012), and (3) non-captured turtles were often lost under floating debris (including oiled debris). In the absence of information on the specific distribution of oiling categories among non-captured turtles, we made the simplifying assumption that the distribution of oiling categories among non-captured turtles was the same as that among captured turtles. Based on this assumption, we allocated non-captured turtles to oiling categories according to the proportions of turtles assigned to each oiling category. For example, if $40 \%$ of captured turtles were lightly oiled, we allocated $40 \%$ of non-captured turtles to the lightly oiled category. However, due to the operational change on 19 July 2010 (whereby non-visibly oiled and apparently vigorous turtles were no longer pursued), we expected the distribution of oiling categories among non-captured turtles to change. Thus, we allocated uncategorized turtles observed before this date based on oiling category proportions documented prior to 19 July, and we allocated those encountered after 19 July based on oiling category proportions documented after this date. We then summed counts of turtles within oiling categories across periods and report both the original and allocated totals.

The sightability of all turtles (oiled and un-oiled) during on-transect searches could have been influenced by multiple factors, including the density of Sargassum, floating debris, color of the turtle and surrounding material, activity level of the turtle, height of the search platform above water, and distance from the vessel. To accurately estimate turtle densities, we corrected for imperfect sightability using line-transect methods (Buckland et al. 2001, 2004). In addition to perpendicular distance, quantifiable sources of variation in sightability were the degree of turtle oiling and observation vessel. For example, sightability could have varied by oiling classification because more heavily oiled turtles were more thoroughly covered by oil and therefore potentially more difficult to see than lightly oiled turtles (e.g. Fig. 2C). In addition, sightability could have varied by vessel due to differences in observation heights, as well as number and placement of observers or Beaufort state. Upon examination, the number of sightings was not sufficient to estimate distance functions by vessel or vessel $\times$ oiling classification. Only 4 of 14 vessels sighted sufficient numbers of turtles (> approx. 35) to support vessel-based distance functions, and only 2 of 70 combinations of vessel and oiling classification contained $>35$ sightings. Rather than estimate separate distance functions for 4 vessels and a combined distance function for 10 others, we chose to combine data from all vessels and estimate distance functions only by oiling category. In addition, all surveys were performed in relatively calm seas (Beaufort state 3 or less, winds of 7 to 10 knots and light whitecaps) with the vast majority conducted in Beaufort state 2 or less. Because of this, realized sample sizes were not sufficient to include Beaufort as a covariate. Additional details of the line-transect methods we used to estimate density are in the Supplement at www.intres.com/articles/suppl/n033p069_supp.pdf.

\section{Total exposure}

Ultimately, the goal of this study was to estimate the abundance of surface-pelagic juvenile sea turtles exposed to DWH oil (i.e. 'total exposure'), as well as the total number of heavily oiled turtles. Both numbers were subsequently used in the DWH NRDA assessment (DWH NRDA Trustees 2015).

Due to oceanographic features and processes, convergence zones in the GoM and the Sargassumbased habitat they create are patchily distributed and ephemeral. Floating habitat in surface convergences zones moves continuously and relatively rapidly (approx. 6 wk to transit the entire spill area; DWH NRDA Trustees 2015, Section 4.4, Hu \& McDonald 2015). During the study period, previously un-oiled Sargassum, and the turtles it contained, could have encountered oil and thereby migrated into the population of interest without drastically increasing the size of the spill's footprint. Likewise, oiled Sargassum could have exited the spill footprint via natural processes (e.g. sinking, wind and wave action) or anthropogenic activities (e.g. burning, dispersant application), thereby changing or turning over the population of Sargassum (oiled and unoiled) in the spill footprint without increasing the footprint's size. In this dynamic state, we assume that some turtles left the population of interest, some were replaced with new individuals, and some individuals remained during the spill period.

The potential for turtle and Sargassum (oiled and unoiled) turnover leads to the conclusion that large numbers of turtles could have been exposed. Consequently, it would not be adequate to use a simple instantaneous estimate (e.g. $1 \mathrm{~d}$ or $1 \mathrm{wk}$ ) of Sargas- 
sum coverage as an estimate of habitat extent. Unfortunately, the information required to quantify the extent and movement of convergence zones, as well as the flux of turtles into and out of those zones does not exist.

To simplify the complex dynamics of convergence zones and turtle movements, and in the absence of specific information, we envisioned a system that allowed us to quantify the approximate 'study area' of the population of interest. The system we envisioned viewed turtle locations as fixed, and convergence-zone (and habitat) locations as circulating throughout the GoM. Envisioning turtles as fixed points allowed us to use the results of Wallace et al. (2017, this Theme Section) to approximate the 'study area.' We were able to apply the model of Wallace et al. (2017) because they estimated, via logistic regression, the average probability that fixed locations within the oil footprint became heavily oiled during the spill period. Because their model utilized satellite-based daily estimates of surface oiling, the model indirectly incorporated currents, convergence zones, and general circulation of waters in the northern
Gulf during the spill period. Wallace et al. (2017) found that the majority of locations, and hence the majority of fixed turtle locations within the footprint, had a positive average probability of heavy oiling during the study (Fig. 4). This result is consistent with rapid transit of waters across the northern GoM. Under this simplification, we envisioned that each turtle at a 'fixed' location would be exposed to oil when the model of Wallace et al. (2017) estimated the turtle's location had non-zero probability of heavy oiling. The results of this method provided the areal extent to which turtle densities were applied. This simplifying assumption is further justified in the 'Discussion'.

Under our simplifying assumption, we applied estimated densities to areas that had non-zero probability of heavy oil exposure to calculate total numbers of turtles exposed. In equation form:

$$
N_{T j}=25\left(\sum_{i=1}^{5} D_{i j}\right)\left[\sum_{\text {pixels }} I\left(p_{5}>0\right)\right]
$$

where $p_{5}$ is the probability of heavy oiling in a pixel (from Wallace et al. 2017), I(e) is the indicator func-

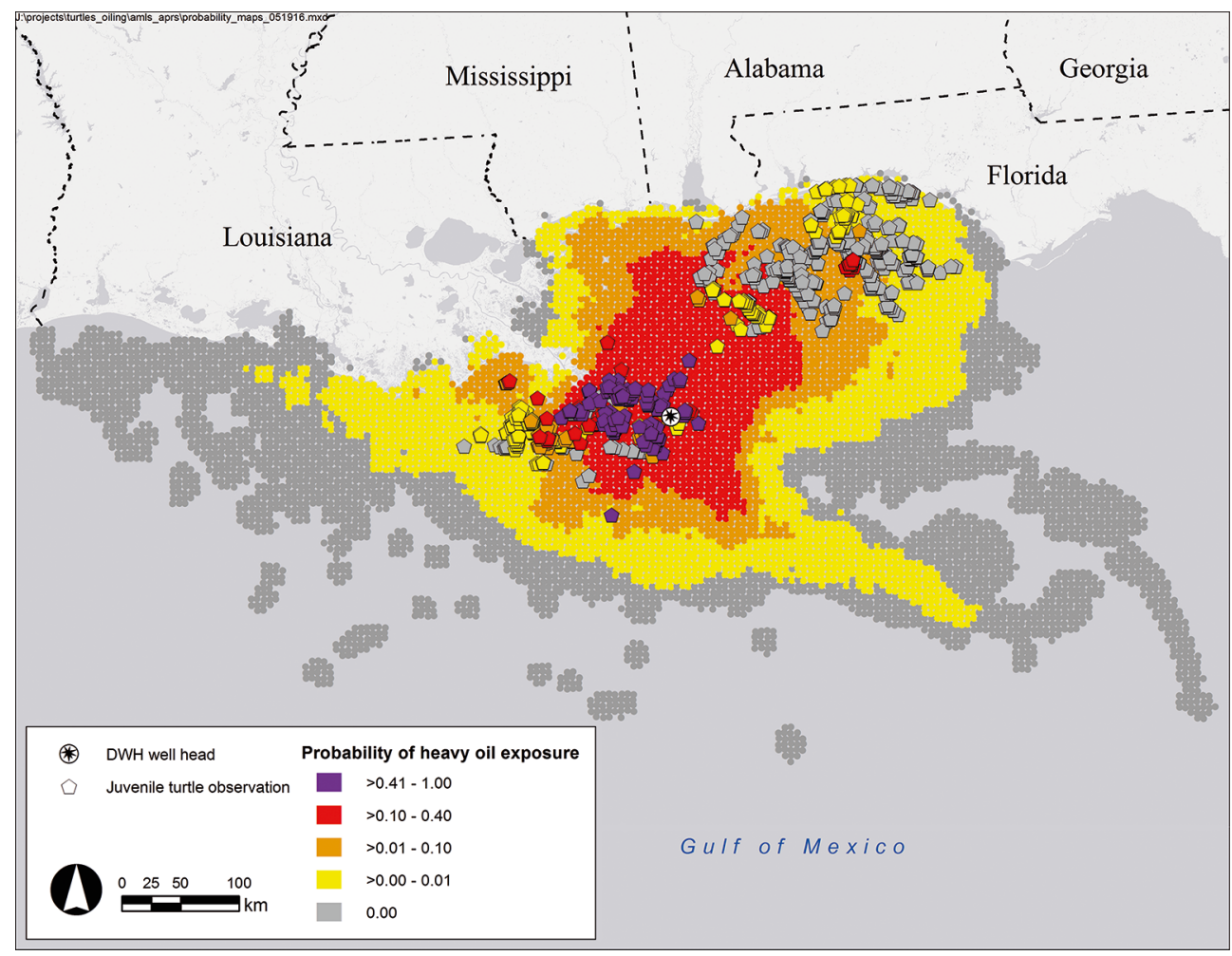

Fig. 4. Modeled probabilities of heavy oil exposure across the Deepwater Horizon (DWH) oil spill zone and period. Colors in pentagons indicate probability of heavy oiling calculated for each turtle captured or sighted during all boat-based rescue operations (on- and off-transect efforts). Background pixel colors indicate mean daily probability of heavy oiling at the centroids of all $5 \times 5 \mathrm{~km}$ grid cells that intersected with the DWH oil footprint. The areal extent of $>0$ probability of heavy oil exposure was $121075 \mathrm{~km}^{2}$. Methods are detailed in Wallace et al. (2017) 
tion for event $e_{\text {; }}$ i.e. $I(e)=1$ if e true, 0 otherwise, and densities were ordered such that non-oiled had index 1 and heavy oiling had index 5 . The area multiplier of 25 was included because pixels were $5 \times 5 \mathrm{~km}$ in size. The first sum, $\sum_{i=1}^{5} D_{i j}$, is the total density of species $j$. The second sum on the right, $\sum_{\text {pixels }} I\left(p_{5}>0\right)$, is the number of pixels with a probability of heavy oiling $>0$. Here, $\sum_{\text {pixels }} I\left(p_{5}>0\right)=4843$. Application of densities to this areal extent assumed that average turtle densities observed during rescue operations adequately reflected actual spatial and temporal variation in turtle densities across the DWH oil footprint.

To estimate the total number of heavily oiled turtles, we applied species-specific heavily oiled densities to those areas estimated by Wallace et al. (2017) to have probability of heavy oiling $>0$ (i.e. yellow areas in Fig. 4). We also recognized that a portion of non-heavily oiled turtles would have been subjected to progressive oiling and would have ultimately entered the heavy oiling category. To account for these individuals, we multiplied the density of non-heavily oiled turtles by the probability of heavy oiling at all pixels in the DWH oil exposure area. In equation form:

$$
N_{H j}=25\left\{D_{5 j}\left[\sum_{\text {pixels }} I\left(p_{5}>0\right)\right]+\left(\sum_{i=1}^{4} D_{i j}\right)\left(\sum_{\text {pixels }} p_{5}\right)\right\}
$$

The second sum, $\sum_{i=1}^{4} D_{i j}$, is the density of nonheavily oiled turtles. The final sum, $\sum_{\text {pixels }} p_{5}$, is the sum of the probabilities in the surface in Wallace et al. (2017) (here, $\sum_{\text {pixels }} p_{5}=336.363$ ). Finally, the difference between total exposures and heavy exposures, $N_{T j}-N_{H j}$, represented turtles that were subject to less-than-heavy oil exposure, but were nonetheless exposed to oil (DWH NRDA Trustees 2015, Section 4.8).

\section{RESULTS}

\section{Turtle rescues and sightings}

A total of 937 surface-pelagic juvenile sea turtles were documented during on- and off-transect searches within the DWH spill area. Of those sighted, 574 were captured during rescue operations and evaluated for oiling status, including 317 Kemp's ridley, 220 green, 19 hawksbill, and 18 loggerhead sea turtles. Most (539 of $574 ; 93.9 \%$ ) of the captured turtles were $<25.0 \mathrm{~cm}$ SCL. The median SCLs for the 4 species were: $22.1 \mathrm{~cm}$ (range $=17.2$ to $65.1 \mathrm{~cm}$ ) for Kemp's ridleys; $21.0 \mathrm{~cm}$ (range $=15.3$ to $31.7 \mathrm{~cm}$ ) for green turtles; $19.8 \mathrm{~cm}$ (range $=14.3$ to 21.5 ) for hawksbills; and 18.7 (range $=6.5$ to $76.0 \mathrm{~cm}$ ) for loggerheads.

In total, 464 sea turtles were visibly oiled and 110 were not visibly oiled. Of all captured oiled turtles (on- and off-transect), 266 were minimally oiled, 87 were lightly oiled, 47 were moderately oiled, and 61 were heavily oiled. There was insufficient information to assess the degree of oiling of 3 turtles. The majority (49 of 61) of heavily oiled turtles were found during May and June, with the remaining 12 captured in July, and all heavily oiled turtles were encountered within a $90 \mathrm{~km}$ straight-line distance from the sea surface coordinates of the wellhead (Stacy 2012, Wallace et al. 2017). The degree of visible oiling on captured turtles declined precipitously at the end of July after placement of a temporary cap on the wellhead on 15 July 2010. Most turtles encountered during August were either minimally oiled or not visibly oiled. Of the 30 turtles encountered between 1 August and 17 September, 3 were minimally oiled and the remaining turtles were not visibly oiled. Moderately and heavily oiled turtles comprised $34.9 \%$ (98 of 281) of sea turtles captured out of ports in Louisiana. Ten moderately oiled sea turtles were documented by operations from Orange Beach, AL, and Destin, FL (10 of 293; 3.4\%); the remaining turtles captured from these ports were lightly oiled, minimally oiled, or not visibly oiled.

Examination of the oral cavities of 432 turtles with visible external oiling indicated that the proportion of turtles with oil in the oral cavity correlated with the degree of visible oiling. The oral cavities of $49.2 \%$ (123 of 250 ) minimally oiled turtles, $76.3 \%$ (61 of 80 ) of lightly oiled turtles, 93.2\% (41 of 44) of moderately oiled turtles and $96.6 \%$ (56 of 58) of heavily oiled turtles contained oil.

A total of 327 live, oiled sea turtles were brought into captivity for cleaning, treatment, and rehabilitation. Three heavily oiled Kemp's ridleys died within $4 \mathrm{~d}$ of capture due to unforeseen complications associated with temporary housing in freshwater. A moderately oiled green turtle died during the fourth month of captivity from severe colitis and secondary septicemia that was not directly attributable to oiling. All of the remaining turtles that were brought into captivity survived and were eventually released into the wild. In addition, 241 live turtles were released at sea shortly after capture, including 106 turtles that were not visibly oiled, 123 that were minimally oiled, 11 that were lightly oiled, and one that was moderately oiled. Prior to release, most or all visible oil was removed using absorbent pads and these releases occurred after the well was temporarily capped on 15 
July 2010, a time when capture crews reported a substantial reduction of oil in convergences.

\section{Field observations related to sea turtle mortality}

Physical fouling in heavy oil presented a clear and serious threat to the survival of sea turtles. Thick, weathering oil impeded mobility and put turtles at risk of exhaustion, dehydration, hyperthermia, and likely decreased the ability to feed and evade predators (Figs. 2C \& 3). Heavily oiled turtles were often mired in oil, lethargic, and palpably warmer than normal upon capture. Surface oil temperatures were opportunistically recorded and were in excess of $120^{\circ} \mathrm{F}$ (approx. $50^{\circ} \mathrm{C}$ ), which is well above the lethal threshold for sea turtles (Jessop et al. 2000, Drake \& Spotila 2002). Postmortem findings in 3 heavily oiled sea turtles that were found dead at sea supported these concerns. Death was attributed to oiling in all 3 cases based on exclusion of other findings, the grave environmental observations associated with heavy oiling, and evidence of asphyxiation or aspiration of oil in 2 turtles. Notably, the esophagus of all 3 turtles was heavily coated with oil, indicating ingestion of relatively large quantities of petroleum. In addition, capture crews regularly encountered oil skimming and burning operations, which were primarily conducted in more heavily oiled areas and presented an additional threat to oiled turtles. Based on these observations and relevance to mortality, it was imperative to understand the extent to which all sea turtles within the spill area were oiled, especially those that were heavily oiled.

\section{Density estimates}

Because only on-transect sightings and captures were used in density estimations, total numbers of turtles reported here differ from the previous sections. Survey crews traversed a total of $4213 \mathrm{~km}$ of transect from 17 May to 9 September 2010. The areas searched were within $1 \mathrm{~d}$ travel time from 1 of 3 ports of operation (Venice, LA; Orange Beach, AL; and Destin, FL) (Fig. 1). A total of 646 juvenile turtles were sighted while on-transect during response efforts in the GoM, of which 406 were captured and brought on board the vessel for examination. Nearly all turtles captured on-transect ( $\mathrm{n}=404)$ were surface-pelagic juveniles; one was a post-hatchling, and one was a subadult. The most common species captured on-transect was Kemp's ridley $(\mathrm{n}=330 ; 51 \%)$, followed by green turtles ( $\mathrm{n}=238 ; 37 \%$ ) (Table 1 ). Size distributions are shown in Fig. 5. Median SCLs of turtles captured on-transect were $22.1 \mathrm{~cm}$ (range = $16.3-27.5 \mathrm{~cm}$ ) for Kemp's ridleys, $21.1 \mathrm{~cm}$ (range = $15.8-31.7 \mathrm{~cm}$ ) for green turtles, $19.8 \mathrm{~cm}$ (range = 14.4-21.5) for hawksbills, and 18.8 (range $=6.5-$ $21.2 \mathrm{~cm}$ ) for loggerheads. Observers could not determine the species for 16 turtles that evaded capture. In addition to those 16 unidentified turtles, 37 loggerheads, 79 green turtles, and $108 \mathrm{Kemp}$ 's ridley turtles (total $=240$ ) that evaded capture (and hence could not be examined) were reallocated to the 5 oiling status categories based on the empirical distribution of oiling before and after 19 July. Final allocated counts are provided in Table 2. Overall, 80.5\% (327 of 406) of turtles captured on-transect were oiled, and this pro-

Table 1. Number of juvenile sea turtles sighted and captured on-transect during the Deepwater Horizon oil spill response efforts in 2010. Turtles sighted on-transect but not captured were assigned the 'unknown' oiling category. All other turtles were captured and assigned into an oiling category based on the extent of oil coverage. During the period from 31 May to 19 July, all turtles sighted were actively pursued for capture. During the period from 20 July to 17 September, vigorously swimming turtles and those thought to be non-oiled were not pursued for capture, but those believed to be oiled were pursued

\begin{tabular}{|c|c|c|c|c|c|c|c|}
\hline Period & Oiling category & Loggerhead & Green turtle & Hawksbill & Kemp's ridley & Unknown & Total \\
\hline 31 May - 19 Jul & Unknown & 15 & 11 & 0 & 20 & 4 & 50 \\
\hline 31 May - 19 Jul & Non-oiled & 0 & 3 & 0 & 4 & 0 & 7 \\
\hline 31 May - 19 Jul & Minimally oiled & 1 & 7 & 0 & 16 & 0 & 24 \\
\hline 31 May - 19 Jul & Lightly oiled & 1 & 8 & 0 & 19 & 0 & 28 \\
\hline 31 May - 19 Jul & Moderately oiled & 1 & 4 & 0 & 10 & 0 & 15 \\
\hline 31 May - 19 Jul & Heavily oiled & 0 & 4 & 0 & 24 & 0 & 28 \\
\hline 20 Jul - 17 Sep & Unknown & 22 & 68 & 0 & 88 & 12 & 190 \\
\hline 20 Jul - 17 Sep & Non-oiled & 4 & 26 & 4 & 38 & 0 & 72 \\
\hline 20 Jul - 17 Sep & Minimally oiled & 3 & 74 & 8 & 88 & 0 & 173 \\
\hline $20 \mathrm{Jul}-17 \mathrm{Sep}$ & Lightly oiled & 1 & 22 & 1 & 12 & 0 & 36 \\
\hline $20 \mathrm{Jul}-17 \mathrm{Sep}$ & Moderately oiled & 0 & 10 & 1 & 9 & 0 & 20 \\
\hline $20 \mathrm{Jul}-17 \mathrm{Sep}$ & Heavily oiled & 0 & 1 & 0 & 2 & 0 & 3 \\
\hline Total & & 48 & 238 & 14 & 330 & 16 & 646 \\
\hline
\end{tabular}


portion matched that for all turtles captured during response operations (i.e. 464 of 575 for on-transect and off-transect together).

Based on the searcher's effective strip width for each oiling category (see the Supplement at www.int-res. com/articles/suppl/n033p069_supp.pdf), we estimated the density of all turtles, after reallocating the 'unknown' oiling category to other categories, to be 3.32 turtles $\mathrm{km}^{-2}\left(95 \% \mathrm{CI}=2.82\right.$ to 3.88 turtles $\mathrm{km}^{-2}$; Table 3), and the density of oiled turtles to be 2.68 turtles $\mathrm{km}^{-2}$ (= sum of density in positive oiling categories). The estimated density of heavily oiled turtles was 0.24 (95\% CI $=0.15$ to 0.39$)$ turtles $\mathrm{km}^{-2}$ in the sampled area, while density of less-than-heavily oiled turtles (including non-oiled) was 3.08 turtles $\mathrm{km}^{-2}$.

\section{Total abundance of turtles exposed to DWH oil}

By multiplying the species-specific density estimates by the area with non-zero probability of heavy surface oiling (Fig. 4), we estimated that more than 402000 surface-pelagic juvenile sea turtles were exposed to DWH oil across more than $121000 \mathrm{~km}^{2}$ of the area of potential oil exposure (Table 4). This number included approximately 206000 Kemp's ridleys, 29800 loggerheads, 148000 green turtles, and 8560 hawksbills. Among these exposures, we estimated more than 54800 turtles were heavily oiled, while the remainder were exposed to oil to lesser degrees (Table 4).

\section{DISCUSSION}

The remote location and depth of the DWH oil discharge posed unique threats to marine resources, particularly surface-pelagic juvenile sea turtles that inhabit areas far from shore. Response efforts to rescue and document surfacepelagic juvenile sea turtles in the DWH spill area in the summer of 2010 (midMay to mid-September) saved hundreds of endangered sea turtles. Although the number of oiled surface-pelagic juvenile turtles sighted and captured during vessel-based searches represented only a portion of affected turtles, turtle density estimates based on these records were combined with modeled probabilities of heavy oiling exposures across the entire DWH spill area (Wal-

Table 2. Number of surface-pelagic juvenile turtles documented on-transect in oiling categories after allocation of turtles not captured (i.e. unknown oiling status) to oiling categories. Turtles that were not captured were allocated based on relative proportions of oiling categories among captured turtles (see 'Density estimates')

\begin{tabular}{|c|c|c|c|c|c|c|}
\hline Oiling category & Loggerhead & Green turtle & Hawksbill & Kemp's ridley & Unknown & Total \\
\hline Non-oiled & 15 & 43 & 4 & 65 & 3 & 130 \\
\hline Minimally oiled & 17 & 122 & 8 & 160 & 8 & 315 \\
\hline Lightly oiled & 10 & 44 & 1 & 43 & 2 & 100 \\
\hline Moderately oiled & 6 & 21 & 1 & 28 & 2 & 58 \\
\hline Heavily oiled & 0 & 8 & 0 & 34 & 1 & 43 \\
\hline Total & 48 & 238 & 14 & 330 & 16 & 646 \\
\hline
\end{tabular}


Table 3. Effective strip width (ESW) and estimated densities by oiling category during response efforts. Densities were computed using Eq. (S1) in the Supplement at www.int-res.com/articles/suppl/n033p069_supp.pdf with number of turtles $\left(n_{i j i}\right)$ equal to the corresponding number in Table 2. Numbers in parentheses are $95 \%$ bias-corrected bootstrap confidence intervals based on 1000 replications and do not sum across rows or down columns. NA: not applicable

\begin{tabular}{|c|c|c|c|c|c|c|c|}
\hline \multirow[t]{2}{*}{ Oil category } & \multirow{2}{*}{$\begin{array}{l}\text { ESW } \\
(\mathrm{m})\end{array}$} & \multicolumn{6}{|c|}{ - Densities (turtles $\mathrm{km}^{-2}$ ) } \\
\hline & & Loggerhead & Green turtle & Hawksbill & Kemp's ridley & Unknown & Total density \\
\hline Non-oiled & 24.3 & $\begin{array}{c}0.0732 \\
(0.0196,0.1509)\end{array}$ & $\begin{array}{c}0.2098 \\
(0.1264,0.3043)\end{array}$ & $\begin{array}{c}0.0195 \\
(0.0043,0.0422)\end{array}$ & $\begin{array}{c}0.3171 \\
(0.2054,0.455)\end{array}$ & $\begin{array}{c}0.0146 \\
(0.005,0.0278)\end{array}$ & $\begin{array}{c}0.6343 \\
(0.446,0.8557)\end{array}$ \\
\hline Minimally oiled & 23.5 & $\begin{array}{c}0.0857 \\
(0.018,0.1811)\end{array}$ & $\begin{array}{c}0.6148 \\
(0.4648,0.7821)\end{array}$ & $\begin{array}{c}0.0403 \\
(0.0163,0.0751)\end{array}$ & $\begin{array}{c}0.8063 \\
(0.6344,1.0084)\end{array}$ & $\begin{array}{c}0.0403 \\
(0.0216,0.067)\end{array}$ & $\begin{array}{c}1.5875 \\
(1.2612,1.8981)\end{array}$ \\
\hline Lightly oiled & 22.1 & $\begin{array}{c}0.0538 \\
(0,0.1491)\end{array}$ & $\begin{array}{c}0.2366 \\
(0.1422,0.3349)\end{array}$ & $\begin{array}{c}0.0054 \\
(0,0.0192)\end{array}$ & $\begin{array}{c}0.2312 \\
(0.141,0.3325)\end{array}$ & $\begin{array}{c}0.0108 \\
(0.0031,0.0181)\end{array}$ & $\begin{array}{c}0.5377 \\
(0.336,0.7309)\end{array}$ \\
\hline Moderately oiled & 21.4 & $\begin{array}{c}0.0332 \\
(0,0.1259)\end{array}$ & $\begin{array}{c}0.1162 \\
(0.0652,0.1929)\end{array}$ & $\begin{array}{c}0.0055 \\
(0,0.0237)\end{array}$ & $\begin{array}{c}0.155 \\
(0.0945,0.2776)\end{array}$ & $\begin{array}{c}0.0111 \\
(0.0055,0.0211)\end{array}$ & $\begin{array}{c}0.3211 \\
(0.2147,0.5129)\end{array}$ \\
\hline Heavily oiled & 21.4 & $\begin{array}{c}0 \\
(0,0)\end{array}$ & $\begin{array}{c}0.0443 \\
(0.0178,0.1118)\end{array}$ & $\begin{array}{c}0 \\
(0,0)\end{array}$ & $\begin{array}{c}0.1882 \\
(0.1125,0.3099)\end{array}$ & $\begin{array}{c}0.0055 \\
(0,0.0133)\end{array}$ & $\begin{array}{c}0.238 \\
(0.1526,0.3873)\end{array}$ \\
\hline Total & NA & $\begin{array}{c}0.2458 \\
(0.1701,0.3222)\end{array}$ & $\begin{array}{c}1.2218 \\
(1.0133,1.4745)\end{array}$ & $\begin{array}{c}0.0707 \\
(0.0388,0.1161)\end{array}$ & $\begin{array}{c}1.6978 \\
(1.4055,2.0019)\end{array}$ & $\begin{array}{c}0.0823 \\
(0.0435,0.1357)\end{array}$ & $\begin{array}{c}3.3186 \\
(2.8185,3.8754)\end{array}$ \\
\hline
\end{tabular}

Table 4. Densities, total exposures, and number of heavily oiled surface-pelagic juvenile sea turtles. Total areal extent with probability of heavy oiling was $121075 \mathrm{~km}^{2}$. Exposure estimates are shown to 3 significant digits

\begin{tabular}{|lccrr|}
\hline Species & $\begin{array}{c}\text { Heavily oiled density } \\
\text { (turtles km }{ }^{-2} \text { ) }\end{array}$ & $\begin{array}{c}\text { Total density } \\
\text { (turtles km }\end{array}$ & $\begin{array}{c}\text { Total turtles } \\
\text { exposed }\end{array}$ & $\begin{array}{c}\text { Total turtles } \\
\text { heavily oiled }\end{array}$ \\
\hline Kemp's ridley & 0.188 & 1.698 & 206000 & 35500 \\
Loggerhead & 0.000 & 0.246 & 29800 & 2070 \\
Green turtle & 0.044 & 1.222 & 148000 & 15300 \\
Hawksbill & 0.000 & 0.071 & 8560 & 595 \\
Unidentified & 0.005 & 0.082 & 9960 & 1310 \\
Total & 0.238 & 3.318 & 402000 & 54800 \\
\hline
\end{tabular}

lace et al. 2017) to quantify the full extent of sea turtle exposures caused by the DWH spill. The DWH NRDA Trustees, a group of scientists and administrators within NOAA who oversaw the NRDA case, used the presence and exposure of sea turtles during rescue operations, as well as our analyses of density and number of exposures, to evaluate the effects of the oil spill. With this and other information, the DWH NRDA Trustees were able to estimate total mortality of turtles in this vulnerable life stage (DWH NRDA Trustees 2015, Section 4.8).

Our estimates of density reflect a temporal average during the survey period in the sampled areas, where sampled areas were predominantly convergence zones containing Sargassum mixed with oil. Expanding these averages, we estimated that a total of 402000 surface-pelagic juveniles were exposed to DWH oil, and that 54800 were heavily oiled (Table 4). To put this number in context, the DWH NRDA Trustees estimated that roughly half of all 1 and $2 \mathrm{yr}$ old Kemp's ridley sea turtles alive at the time of the
DWH spill were exposed to oil. The Trustees were able to estimate this proportion because the majority of Kemp's ridleys nest in one region where it is possible to measure total hatchling production. With associated information on somatic growth rates and plausible survivorship, the Trustees compiled a fair understanding of the 1 and $2 \mathrm{yr}$ old cohort abundance. The Trustees concluded that the exposure estimates we present here were plausible given what is known about Kemp's ridley abundance, habitat affinities, life history, and circulation in the GoM. The Trustees estimated that approximately 10 to $20 \%$ of all 1 and 2 yr old Kemp's were killed by the spill (DWH NRDA Trustees 2015, Section 4.8). We cannot say with certainty whether these estimated proportions for Kemp's ridleys apply to other species because the distribution of surface-pelagic juvenile turtles in the GoM is likely to be non-uniform. Kemp's ridleys may have active swimming and orientation behavior that favors a northern GoM distribution, whereas juveniles of at least one other species, the green turtle, appear to orient movements favoring an exit from the GoM (Putman \& Mansfield 2015).

\section{Uncertainties in density estimates}

There is some unquantified uncertainty associated with the density and exposure estimates reported here (Tables $3 \& 4$ ). Multiple uncontrolled and un- 
quantified factors have likely caused a negative bias in our DWH oil-spill-affected surface-pelagic juvenile turtle density estimates. These factors include (1) imperfect sightability on transect lines, (2) turtle carcasses that were likely poorly visible or unavailable to observers in sampled areas, (3) our inability to sample near the wellhead just after and during the spill, and (4) post-hatchlings that were not sighted or were unavailable for sampling. In the remainder of this subsection, we discuss each of these factors in turn.

First, the density estimates contained in Table 3 are potentially negatively biased by the assumption of perfect detection either on the transect line or at some distance within $10 \mathrm{~m}$ of the boat (i.e. at the mode of the Gamma function). It is likely that perfect detection was not achieved because some turtles in all oiling categories were likely concealed within dense oil or Sargassum (or both) and could not be observed. Furthermore, we were unable to retrospectively assess the magnitude of detection probabilities on or near transects because the presence of surface oil was an important factor influencing sightability. As guidance on the magnitude and direction of this bias, we note that if detection probability near the vessels was $x$ (approx. $0.6<x<1$ ), resulting densities would increase relative to those in Table 3 by a factor of approximately $1 / x$.

Second, dead turtles were likely lost from the sampled population relatively rapidly. The specific gravity of sea turtles is greater than seawater (Milsom 1975); consequently, when a turtle dies, the carcass most likely sinks. This assumption is consistent with anecdotal observations from aquaria, rehabilitation centers, and fisheries observers. Furthermore, the depth of the waters involved (generally $>100 \mathrm{~m}$ ) make it unlikely that decomposition gases could expand the carcass (i.e. bloat) to an extent that it would resurface after sinking. If turtle carcasses were entrained in floating oil, they would be subject to both scavenging and relatively high decomposition rates in midsummer water-surface temperatures (approx. $30^{\circ} \mathrm{C}$ ). In addition, carcasses do not actively move like live turtles, and therefore lack an important visual detection cue for discovery. Given these factors, the most reasonable assumption is that the majority of dead turtles were unavailable for sighting, which is consistent with the discovery of relatively few dead oiled turtles during field operations. This assumption implies that the true density of turtles affected by the oil spill was higher than the numbers reported in Table 3.

Third, rescue efforts were unable to adequately sample turtles throughout the entire spill area, particularly around the wellhead. During directed capture efforts, numerous operations to secure and cap the DWH wellhead were ongoing, and oil response crews were actively burning surface oil in the vicinity. Due to vessel-traffic restrictions near burn zones and restricted access near the wellhead, few directed turtle capture surveys were performed within approx. $10 \mathrm{~km}$ of the wellhead. Thus, the area where turtles had the highest probability of becoming heavily oiled (Fig. 4; Wallace et al. 2017) was poorly sampled. In addition, regular search effort was not initiated until more than 1 mo after the blowout. Thus, turtle captures and degrees of oiling during the first month of the spill were unrepresented, and the initial survey period was underrepresented because survey efforts were still increasing in number and extent. It is reasonable to assume that surface-pelagic juvenile turtles were present in the area of highest probability of heavy surface oiling, and had crews been allowed to search there, particularly during the first month of the spill, the proportion of oiled turtles in the sample would have been higher than proportions observed elsewhere. This further suggests that the true density of turtles affected by the oil spill was higher than the densities reported in Table 3, especially for the more severely oiled categories.

Fourth, density estimates did not include posthatchling turtles. Post-hatchling loggerhead, green, and Kemp's ridley turtles are known to inhabit the northern GoM because these species nest on GoM beaches (Bolten 2003, Bolten \& Witherington 2003, NMFS et al. 2011). Despite this, only 1 oiled posthatchling loggerhead was recovered in the northern GoM in 2010 (Stacy 2012). Three factors were likely to have affected the number of post-hatchlings observed: low detectability, high mortality, and reduced numbers in the surveyed habitat. Live post-hatchlings would be expected to have a lower probability of detection than juveniles because of the post-hatchlings' small size (approximately 19 to $100 \mathrm{~g}$ ), cryptic coloration, and minimal movement. These small turtles would be especially difficult to see if they were oiled or were within oiled surface habitat. High mortality in post-hatchlings might be expected due to their vulnerability to surface oil and propensity to ingest tar balls (Witherington 2002). If post-hatchlings ingested tar balls originating from the spill, it is reasonable to assume that a certain proportion died and were scavenged or sank, and consequently became unavailable for sampling. Importantly, following the spill in 2010 the DWH NRDA Trustees decided to translocate known Kemp's ridley and loggerhead nests from northern GoM beaches to the Atlantic coast of Florida and away from the spill's effects. Translocation of known nests undoubtedly con- 
tributed to the rarity of post-hatchling observations. Despite the Trustees' translocation efforts, any posthatchlings entering the northern GoM from nests left in situ or entering the spill zone from outside areas could have encountered oil. While we feel the strongest hypothesis is that some post-hatchlings were affected by oil but were not available for sampling, we unfortunately cannot quantify these losses with any degree of confidence. If it is true that posthatchlings were present but undetected, our estimates will underrepresent the total number of turtles impacted by the spill.

\section{Uncertainties in exposure estimates}

In addition to sources of negative bias in our estimates of DWH oil-spill-affected abundance, one unquantified source of positive bias was that we primarily sampled convergence zones. This bias is unquantified because we could not quantify the dynamics of turtles entering Sargassum, Sargassum entering convergence zones, or convergence zone spatial structure and movement. Because we could not quantify these dynamics, we relied on a model for the probability that fixed locations would become heavily oiled in order to expand exposed densities into exposed abundance, and this model may have overestimated the expansion factor or size of the 'study area'. Here, 'study area' depends on habitat movements into and out of oiled areas, as well as the flux of turtles into and out of both habitat and convergence zones.

Recall that in our simplifying assumption, we viewed turtle locations as fixed while convergence zones (and habitat) were viewed as circulating throughout the GoM. This assumption allowed us to apply the results of Wallace et al. (2017) to approximate the 'study area' as the areal extent of areas with non-zero oiling probability. Under this simplification, we effectively multiplied densities (heavily oiled and total) by the size of the 'study area'.

A key challenge to our simplifying assumption is that turtles do not remain fixed in a single geographic location. Turtles are thought to generally reside in and move with convergence zones, but Mansfield et al. (2014) and Putman \& Mansfield (2015) demonstrated this is not always the case. Juveniles can move independently of convergence zones. Nonetheless, it is possible that our method 'double counted' some turtles when they moved, either because the convergence zone moved or because they swam. In the absence of information on the relevant rates that would allow us to estimate turtle population turnover in convergence zones, we cannot provide a quantitative estimate or adjustment for this potential 'double counting'. We can, however, justify our approach as follows.

First, our approach, which assumed fixed turtle locations, caused positive bias. In many management situations like this one, an upper limit, even if it includes some positive bias, is the quantity of interest and is often deemed acceptable. Second, the positive bias induced by our simplifying assumption is partially or wholly offset by negative biases contained in our density estimates. If we could somehow remove negative biases from density, and positive bias from the expansion factor, net estimated exposures could increase or decrease. Finally, considering data limitations, we stress that there was no better method to construct our expansion factor. A more informed analysis, including detailed, quantitative data on instantaneous and cumulative areal extents of convergence zones, Sargassum, and turtle movements among surface-pelagic habitat, is not possible at this time due to data limitations.

\section{CONCLUSIONS}

Despite uncertainties, our density and exposure estimates were based on the best available data and methods, were derived using a repeatable technical approach, and were reasonable when compared to at least one independent study. Witherington et al. (2012) reported higher densities of surface-pelagic juveniles within Sargassum habitat in the GoM $\left(7.0 \mathrm{~km}^{-2} ; 95 \%\right.$ $\mathrm{CI}=4.8$ to 10.2 ), a relatively small difference explainable by methodology. Thus, we and the DWH NRDA Trustees consider our density estimates to be biologically plausible even if slightly low (for reasons given above). Further, a plausibility test for exposures can be constructed for surface-pelagic juvenile Kemp's ridley turtles, which are sufficiently abundant within the spatial and temporal extent of the DWH spill to accommodate our estimated densities.

Although it remains to be determined whether oil exposure and mortality in 1 (or 2) year classes will have long-term population-level effects, demographic losses of this scale are a significant concern given that all species studied here are threatened with extinction. Disturbingly, Kemp's ridleys have failed to meet projected nesting numbers since 2010, and recovery of this species to historic numbers has slowed in recent years (Caillouet et al. 2016). Future monitoring of nesting and other abundance measures may yield insight into possible population-level effects of the DWH spill, but limitations should be 
anticipated due to difficulty in disentangling spill effects from other anthropogenic and non-anthropogenic factors. Nonetheless, our results characterized the magnitude of exposure of surface-pelagic juvenile sea turtles to DWH oil and informed estimates of total surface-pelagic juvenile mortality, which are important for framing hypotheses related to potential long-term effects.

So that future assessments of harm to sea turtles from catastrophic events are informed, we strongly recommend continued assessment of turtle density, abundance, movement, and areal extent of habitat (primarily Sargassum). Such monitoring will provide critical pre-event data against which post-event data can be compared.

Acknowledgements. This work was part of the DWH Natural Resource Damage Assessment (NRDA) being conducted cooperatively among NOAA, other federal and state Trustees, and BP PLC. This work would not have been possible without the significant efforts of many dedicated individuals that contributed tirelessly during the DWH oil spill. Personnel from the Inwater Research Group, Florida Fish and Wildlife Conservation Commission, NOAA/NMFS, Riverhead Foundation for Marine Research and Preservation, University of Florida, Georgia Department of Natural Resources, and others conducted rescue operations in cooperation with Gulf of Mexico charter vessel captains and crews. Personnel from the Louisiana Department of Wildlife and Fisheries conducted rescue operations using department vessels and staff from the Office of Fisheries and the Law Enforcement Division. Personnel from NOAA/NMFS within the DWH Unified Command provided critical shorebased support. Additional support was provided by ground transportation crews and rehabilitation facilities that cared for oiled turtles.

\section{LITERATURE CITED}

Bolten AB (2003) Variation in sea turtle life history patterns: neritic versus oceanic developmental stages. In: Lutz PL, Musick JA, Wyneken J (eds) The biology of sea turtles, Vol 2. CRC Press, Boca Raton, FL, 243-257

Bolten AB, Witherington BE (eds) (2003) Loggerhead sea turtles. Smithsonian Institution Press, Washington, DC

Buckland ST, Anderson DR, Burnham KP, Laake JL (2001) Introduction to distance sampling: estimating abundance of biological populations. Oxford University Press, Oxford

Buckland ST, Anderson DR, Burnham KP, Laake JL, Borchers DL, Thomas L (2004) Advanced distance sampling. Oxford University Press, Oxford

Butler JN, Stoner AW (1984) Pelagic Sargassum: Has its biomass changed in the last 50 years? Deep-Sea Res 31 1259-1264

Butler JN, Morris BF, Cadwallader J, Stoner AW (1983) Studies of Sargassum and the Sargassum community.

Editorial responsibility: Nicolas Pilcher (Guest Editor), Sabah, Malaysia
Bermuda Biological Station Special Publication No. 22, St. Georges

Caillouet CW, Gallaway BJ, Putman NF (2016) Kemp's ridley sea turtle saga and setback: novel analyses of cumulative hatchlings released and time-lagged annual nests in Tamaulipas, Mexico. Chelonian Conserv Biol 15:115-131

NDrake DL, Spotila JR (2002) Thermal tolerances and the timing of sea turtle hatchling emergence. J Therm Biol 27: 71-81

DWH NRDA Trustees (2015) Final programmatic damage assessment and restoration plan (PDARP) and final programmatic environmental impact statement (PEIS). www. gulfspillrestoration.noaa.gov/restoration-planning/gulfplan/ (accessed 30 Aug 2016)

Hu C, Hardy R, Ruder E, Geggel A and others (2016) Sargassum coverage in the northeastern Gulf of Mexico during 2010 from Landsat and airborne observations: implications for the Deepwater Horizon oil spill impact assessment. Mar Poll Bull 107:15-20

Jessop TS, Hamann M, Read MA, Limpus CJ (2000) Evidence for a hormonal tactic maximizing green turtle reproduction in response to a pervasive ecological stressor. Gen Comp Endocrinol 118:407-417

Mansfield KL, Wyneken J, Porter WP, Luo J (2014) First satellite tracks of neonate sea turtles redefine the 'lost years' oceanic niche. Proc R Soc B 281:2013.3039

Milsom WK (1975) Development of buoyancy control in juvenile Atlantic loggerhead turtles, Caretta c. caretta. Copeia 1975:758-762

NMFS, USFWS, SEMARNAT (2011) Bi-national recovery plan for the Kemp's ridley sea turtle (Lepidochelys kempii). National Marine Fisheries Service, Silver Spring, MD. https://pub-dwhdatadiver.orr.noaa.gov/dwhar-documents/894/DWH-AR0088391.pdf

Putman NF, Mansfield KL (2015) Direct evidence of swimming demonstrates active dispersal in the sea turtle 'lost years'. Curr Biol 25:1221-1227

Stacy BA (2012) Summary of findings for sea turtles documented by directed captures, stranding response, and incidental captures under response operations during the BP Deepwater Horizon (Mississippi Canyon 252) oil spill. DWH NRDA Technical Report No. DWH-AR0149670, NOAA, NMFS US Department of Commerce, Washington, DC. https://pub-dwhdatadiver.orr.noaa.gov/dwh-ardocuments/894/DWH-AR0149670.pdf (accessed 30 Aug 2016)

Thiel M, Gutow L (2005) The ecology of rafting in the marine environment. II. The rafting organisms and community. Oceanogr Mar Biol Annu Rev 43:279-418

USCG (2012) On scene coordinator report: Deepwater Horizon oil spill. www.uscg.mil/foia/docs/dwh/fosc_dwh_ report.pdf (accessed 30 Aug 2016)

Wallace BW, Stacy BA, Rissing M, Cacela D and others (2017) Estimating sea turtle exposures to Deepwater Horizon oil. Endang Species Res 33:51-67

Witherington BE (2002) Ecology of neonate loggerhead turtles inhabiting lines of downwelling near a Gulf Stream front. Mar Biol 140:843-853

Witherington BE, Hirama S, Hardy R (2012) Young sea turtles of the pelagic Sargassum-dominated drift community: habitat use, population density, and threats. Mar Ecol Prog Ser 463:1-11

Submitted: February 8, 2016; Accepted: September 9, 2016 Proofs received from author(s): November 16, 2016 